\title{
Effects of Evening Primrose Oil and Evening Primrose-rosemary Mixed Oil on Atopic Dermatitis-induced Animal Model
}

\author{
Seon Ju Kim, Shin Hee Park \\ Department of Complementary and Alternative Medicine, Chosun University, Gwangju, Korea
}

\author{
*Corresponding author: Shin Hee Park, \\ Department of Complementary and Alternative \\ Medicine, Chosun University, 309 Pilmun- \\ daero, Dong-gu, Gwangju 61452, Korea \\ Tel.: +82 624188740 \\ Fax: +8262970 0491 \\ Email: sini88@hanmail.net
}

Received April 7, 2017

Revised August 11, 2017

Accepted September 5, 2017

Published December 30, 2017

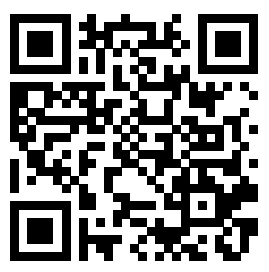

\begin{abstract}
Purpose: This study aimed to explore the possibility of using evening primrose oil (E oil) and evening primrose-rosemary mixed oil (ER oil) as alternative substances for treating atopic dermatitis (AD). Methods: NC/Nga mice were divided into the control, AD-induced, E oil-treated, and ER oil-treated groups. Each group was treated for 6 days. Thereafter, the effects of anti-oxidation and lipid peroxidation activity (LPA) were analyzed. In addition, tissue biopsy samples were observed under a microscope, immunoglobulin E (IgE) levels were measured, and the effects of mast cell degranulation were assessed. Results: Compared with the control group, the E oil- and ER oil-treated groups showed increased electron donating activity (EDA) and LPA. The epidermal thicknesses were less in the E oil- and ER oil-treated groups than in the $A D$-induced group and recovered to a degree similar to that of the control group. Quantitative measurements showed decreased lgE levels in the E oiland ER oil-treated groups compared with those in the AD-induced group. Mast cell degranulation was reduced in the E oil- and ER oil-treated groups compared with that in the AD-induced group. Conclusion: The study results showed that herb oils such as E oil and ER oil can potentially be used for treating dermatitis and that oils with two or more herb oils improved the results.
\end{abstract}

Keywords: Evening primrose oil, Rosemary oil, Atopic dermatitis, Anti-oxidant effects, Aromatherapy

\section{Introduction}

아토피피부염(AD)은 피부알러지의 대표적인 질환으로서 최근 발병률이 증가하고 있으며(Horiuchi et al., 2004), 흔히 태열이 라고도 불리는 만성피부질환으로서 소양감을 비롯한 피부건조, 염증과 같은 현상이 주로 나타난다(Horrobin, 2000). 2000년대 로 접어들면서 $\mathrm{AD}$ 의 발병률은 $15-30 \%$ 로 크게 증가하였으며, 다 양한 연령대에서 발병되는데 특히 어린이에게서 더 많이 나타나 는 추세로 1 세 미만의 발병률이 가장 높고 $85 \%$ 가 5 세 이전에 나 타난 것으로 보고되었다(Heo et al., 2008; Yoon et al., 1999).

$\mathrm{AD}$ 의 발병요인으로는 유전적인 요인과 환경적인 요인, 복 합적인 요인으로 알려져 있으며, 활성산소(reactive oxygen species, ROS)를 비롯한 IgE 및 cluster of differentiation $\left(\mathrm{CD} 4^{+}\right)$보조 $\mathrm{T}$ 림프구 $\left(\mathrm{CD} 4^{+} \mathrm{T}\right.$ cells, $\mathrm{T}$ helper cells; Th cells) 에 의한 interleukin 4 (IL4)나 tumor necrosis factor alpha
$(\mathrm{TNF} \alpha)$ 와 같은 사이토카인(cytokine)들이 관여하고 있는 것으 로 알려져 있다(Hanifin, 1982; Kalliomäki et al., 2001). 특히 $\mathrm{Th}$ 세포는 $\mathrm{AD}$ 에 중요한 역할을 하는데 Th1 세포는 interferon gamma ( $\mathrm{IFN} \gamma$ )나 $\mathrm{TNF} \alpha$ 를 분비하여 피부 진피층의 비후나 염 증에 관여하며, Th2 세포는 IL4와 같은 사이토카인을 분비하여 $\mathrm{IgE}$ 의 아형변화(isotype switching) 및 병변부위로 호산구의 이 송을 촉진시켜 염증발생을 유도한다(Fridovich, 1975).

염증반응 시 대식세포나 단핵구의 표면에 $\mathrm{IgE}$ 수용체 (receptor) 표현이 증가되는데, 항원이 $\mathrm{IgE}$ 의 수용체를 자극하 게 될 경우 단핵구나 대식세포가 활성화되면서 granulocytemacrophage colony-stimulating factor (GM-CSF)를 분비하 여 염증반응을 더욱 가속화한다(Bratton et al., 1995). 더욱이 자극을 받은 식세포들은 세포형질막에 존재하는 nicotinamide adenine dinucleotide phosphate (NADPH) oxidase를 통해 $\mathrm{ROS}$ 의 증가를 유발하는 호흡분출(respiratory burst)을 유도하 
며(Jung et al., 2003), IgE 수용체는 탈과립된 비만세포와 결 합하여 소양감을 유발하고 병변을 더욱 악화시킨다고 한다(Sudo et al., 2001; Yamashita et al., 2005). 따라서 아토피피부염은 $\mathrm{IgE}$ 를 비롯한 비만세포 및 $\mathrm{ROS}$ 와 같은 인자들의 상호복합적인 작용의 결과에 기인한다고 알려져 있다(Metzger, 2004; Oh et al., 2005).

$\mathrm{AD}$ 의 발병률 증가추세에 비하여 아직까지 $\mathrm{AD}$ 에 대한 자세한 작용기전이나 치료에 효과적인 약물의 개발이 미흡한 상태이다. 그러나 ROS가 병변요인 중 하나로 밝혀지면서 항산화 측면에서 치료적 접근을 시도하고 있다(Huh et al., 2004; Seo, 2014).

최근 허브를 비롯한 한약재 및 약용식물들의 성분에는 항산화 를 비롯한 항암, 항염, 항균 등과 같은 다양한 생리활성을 나타 내는 물질들이 함유되어 있다고 밝혀져 있다(Oh et al., 2011; Seo \& Jeong, 2015). 허브에서 생성되는 오일과 같은 추출물 들은 항산화, 항염, 항균 등에 좋은 terpineol이나 santalol, menthol, pinene과 같은 유효성분들을 다량 함유하고 있어 오 래 전부터 의약품의 대용으로 사용하여 왔다(Hou \& Li, 2011; Owlia et al., 2007). 허브오일 중 로즈마리오일[rosemary (Rosmarinus officinalis) oil; R oil]과 달맞이꽃종자유[evening primrose (Oenothera biennis) oil; $\mathrm{E}$ oil]는 $\mathrm{AD}$ 와 같은 염증 병변에 좋은 효능이 있다고 알려져 있다(Battaglia, 2004). R oil은 cineol을 비롯한 camphor, pinene, bornyl acetate 및 limonene 등의 성분을 함유하고 있으며 이들은 항산화를 비롯 한 항염, 항암 등에 유효한 생리활성을 가지고 있다고 알려져 있 다(Peng et al., 2007). E oil는 항산화에 좋은 linoleic acid를 비롯한 palmitic acid, stearic acid, gamma linolenic acid 및 oleic acid와 같은 성분을 함유하고 있어 항산화 및 항균, 항알러 지 등에 유효한 효능이 있다고 알려져 있다(Han et al., 2002).

본 연구는 $\mathrm{E}$ oil와 $\mathrm{E}$ oil에 $\mathrm{R}$ oil을 첨가한 달맞이꽃종자유-로 즈마리 혼합오일(evening primrose-rosemary mixed oil; ER oil)을 재료로, $\mathrm{AD}$ 모델인 $\mathrm{NC} / \mathrm{Nga}$ 생쥐에 대한 체중과 장기 무
게변화 및 관능평가와 항산화 효과를 분석하고, 생쥐의 조직으로 부터 면역지표인 $\mathrm{IgE}$ 의 측정과 비만세포의 탈과립 및 피부장벽 의 변화를 연구하여 $\mathrm{AD}$ 의 치료적 대체물질로의 활용가능성을 탐 색하기 위해 연구를 시행하였다.

\section{Methods}

\section{1. 실험 동물}

본 실험에 사용한 동물은 태령 6주령인 $\mathrm{NC} / \mathrm{Nga}$ 생쥐를 (주) 중앙실험동물(Korea)에서 구입한 후 케이지에 넣고 1주일 동안 적응기간을 거친 후 본 실험에 사용하였다. 대조군과 각각의 실 험군은 $\mathrm{AD}$ 유발군, $\mathrm{E}$ oil 처치군 및 $\mathrm{ER}$ oil 처치군으로 나누어 6 일 동안 처리하였다. 각 군당 개체수는 Festing et al. (1998)의 오차자유도의 공식에 따라 6 마리씩 24 마리를 무작위로 배정하였 다.

\section{2. 실험 재료 및 시약}

본 실험에 사용한 에센셜오일은 G.R. Davis Pty. (Australia) 의 제품을 사용하였고, 2,2-diphenyl-1-picrylhydrazyl (DPPH), 1-chloro-2,4-dinitrobenzene (DNCB), ammonium thiocyanate, linoleic acid, ferrous chloride, neutral buffered formalin (NBF), hydrogen chloride ( $\mathrm{HCl})$-alcohol, Harris hematoxylin 용액, eosin-alcohol dehydrate 용액, 올 리브유(olive oil), 아세톤(acetone), 에탄올(ethanol)은 SigmaAldrich (USA)의 제품을, 파라핀(paraffin), toluidine blue solution은 Wako Pure Chemical Industries (Japan)의 제품 을, IgE enzyme-linked immunosorbent assay (ELISA) kit 는 KOMA BIOTECH (Korea) 제품을 구입하여 사용하였다.

\section{Table 1. Components of E oil and R oil}

\begin{tabular}{llcc}
\hline Division & Component & Compound & Content (\%) \\
E oil & & Salmitic acid & 6.5 \\
& & & 1.3 \\
& Oxides & Stearic acid & 0.3 \\
& & Arachidic acid & $40.1-49.1$ \\
& Monoterpene hydrocarbons & 1,8 -Cineole & $10.3-26.9$ \\
R oil & & $\alpha-$-Pinene & $4.3-7.7$ \\
& Ketones & B-Pinene & $2.0-4.9$ \\
& Esters & Limonene & $9.9-20.7$ \\
& Sesquiterpene hydrocarbons & Camphor & $1.0-13.2$ \\
\hline
\end{tabular}

E oil, Evening primrose oil; R oil, Rosemary oil. 


\section{3. 오일 성분 및 오일 제조방법}

1) 오일의 성분

$\mathrm{E}$ oil과 R oil의 성분을 Table 1에 나타내었다.

\section{2) 시료액 제조방법}

ER oil의 제조는 Battaglia (2004)의 사용지침서의 권장에 따 라 R oil $100 \mathrm{~mL}$ 에 E oil $2 \mathrm{~mL}$ 넣어 $2 \%$ 로 혼합하여 차광병에 보관 및 사용하였다.

오일의 각 시료액 제조는 각 오일 $100 \mathrm{~mL}$ 에 에탄올 $1 \mathrm{~mL}$ 를 넣어 전체 총액의 $1 \%$ 에 해당하는 에탄올로 녹인 후 각각 10,50 , 100,150 및 $200 \mu \mathrm{L}$ 의 저장액을 만들어 냉암소에 보관하였다. 실험에 필요한 오일농도는 저장액을 최종 농도로 희석 후 사용하 거나 또는 직접 필요한 농도를 배양액에 첨가하여 사용하였다.

\section{4. $A D$ 유발 및 시료액 도포}

$\mathrm{AD}$ 의 유발을 위하여 아세톤과 올리브유를 $3: 1$ 의 비율로 섞어 총량을 $100 \mathrm{~mL}$ 만든 후 여기에 $\mathrm{DNCB} 1 \mathrm{~g}$ 을 첨가하여 잘 섞어 $1 \%$ 의 저장액을 만든 후 냉암소에 보관 실험에 사용하였다.

$\mathrm{AD}$ 유발 및 오일 도포는 Matsuda et al. (1997)의 방법을 따 라 진행하였다. NC/Nga 생쥐의 등 부위를 깨끗이 제모 한 후 4 $\mathrm{h}$ 동안 진정시킨 다음 $1 \% \mathrm{DNCB}$ 용액 $200 \mu \mathrm{L}$ 를 도포한 다음 4 일 후부터 $0.2 \% \mathrm{DNCB}$ 용액 $150 \mu \mathrm{L}$ 을 2 회/일, 3 주간 도포하였 다.

$\mathrm{AD}$ 유발에 대한 병변 상태는 Yamashita et al. (2009)의 판 정에 따라 확인하였다. 병변에 따른 총 점수[modified scoring atopic dermatitis (SCORAD) index]를 15점으로 할 경우 10점 이상을 $\mathrm{AD}$ 유발로 판정하였다.

시료액 도포는 E oil과 하루 전에 조제한 $\mathrm{ER}$ oil $150 \mu \mathrm{L}$ 를 각 각 $\mathrm{AD}$ 유발 후 매일 2회씩 6 일 동안 도포한 후 회복효과를 조사 하였다.

\section{5. 체중 및 장기 무게측정}

체중(body)과 장기(organ)의 무게측정은 $\mathrm{AD}$ 유발 직전과 $\mathrm{AD}$ 유발 종료 직후 및 오일 처치 종료 직후에 대하여 각각 측정 하였다. 체중과 장기 무게측정은 전자체중계(Mettler-Toledo, Switzerland)를 사용하였다. 장기 무게측정 시 경추탈골을 시행 한 직후 개복한 다음 측정하였다.

\section{6. 관능평가}

관능평가(sensory assessment)에 의한 병변의 진행 정도 를 측정하기 위하여 Yamashita et al. (2009)의 판정방법에 따라 홍반(erythema), 부종(edema), 소양(pruritus), 찰과상 (excoriation), 각피/건조(scaling/dryness)로 나누고, 각각 modified SCORAD index를 3점씩 총 15점으로 하였다. 0점은
변화 없음, 1 점은 작은 변화나 약간의 증상, 2 점은 중등도의 변 화(유발부위의 $1 / 3$ 정도), 3 점은 심한 변화(유발부위의 $2 / 3$ 정도) 로 구분하였다.

\section{7. 전자공여능 분석}

전자공여능(EDA)의 측정은 Blois (1958)의 방법에 따라 에탄 올에 녹인 시료용액 $2 \mathrm{~mL}$ 에 $1 \mathrm{~mL}$ 의 $0.2 \mathrm{mM}$ 의 $\mathrm{DPPH}$ 를 넣은 후 이를 vortex mixer (Scientific Industries, USA)를 이용하 여 혼합 후 실온에서 $30 \mathrm{~min}$ 동안 정치한 다음 ELISA reader (Scientific Industries)로 $517 \mathrm{~nm}$ 에서 흡광도를 측정하여 대조 군과 비교 조사하였다. $\mathrm{EDA}$ 는 시료용액 첨가군과 무첨가군의 흡 광도 감소율을 백분율로 표시하였다.

\section{8. 지질과산화능 분석}

지질과산화능(LPA)의 측정은 Kikuzaki \& Nakatani (1993) 의 방법에 따라 에탄올에 녹인 시료용액을 에탄올에 녹인 $2.52 \%$ linoleic acid와 $0.05 \mathrm{M}$ phosphate buffered saline (PBS; pH 7.0)의 혼합용액에 넣어 $40^{\circ} \mathrm{C}$ 의 암소에서 $24 \mathrm{~h}$ 동안 배양하였 다. 배양 완료 후 $0.1 \mathrm{~mL}$ 의 반응액을 취하여 $30 \%$ ammonium thiocyanate와 $0.02 \mathrm{M}$ ferrous chloride를 첨가하여 실온에서 $1 \mathrm{~h}$ 동안 방치하였다. 방치 후 ELISA reader로 $500 \mathrm{~nm}$ 에서 흡 광도를 측정하여 대조군과 흡광도를 비교 조사하였다. 지질과산 화는 대조군에 대한 백분율로 표시하였다.

\section{9. 표피두께 측정}

표피두께(epidermal thickness)의 측정은 생검한 조직을 10\% $\mathrm{NBF}$ 로 고정한 후 파라핀으로 포매 후 초박 절편기를 이용하여 $5 \mu \mathrm{m}$ 의 두께로 절편하였다. 탈 파라핀 과정과 알코올 함수과정 을 거쳐 Harris hematoxylin 용액과 $1 \% \mathrm{HCl}-\mathrm{alcohol}$ 의 처리를 거친 후 ammonia water와 lithium carbonate에 재처리 후 증 류수로 세척 후 절편을 $1 \%$ eosin-alcohol dehydrate 용액에 3 $\min$ 동안 처리하였다. 처리 완료 후 탈수와 투명과정을 거쳐 봉 입 후 광학현미경(Olympus BX50; Olympus, Japan)으로 관찰 하였다. 모든 영상은 광학현미경으로 확대한 후 영상카메라로 포 착하여 TIF (tagged image file)로 저장하였으며, 포착한 영상 은 현미경의 빛 강도와 영상분석프로그램을 통하여 $450 \mathrm{MHz}$ 펜 티엄 프로세스와 영상보드(Media Cybernetics, USA)가 장착된 컴퓨터시스템을 이용하여 측정하였다.

\section{0. $\lg E$ 분석}

혈액 채취는 생쥐의 눈외자를 헤파린(heparin)이 도포된 capillary tube로 찔러 $1.5 \mathrm{~mL}$ 를 채혈한 후 $4^{\circ} \mathrm{C}, 3,000 \mathrm{rpm}$ 에서 $20 \mathrm{~min}$ 동안 원침한 다음 상등액을 취하여 $-70^{\circ} \mathrm{C}$ 에 보관 사용하였다. $\operatorname{IgE}$ 분석은 IgE ELISA kit를 이용하여 일차항체 


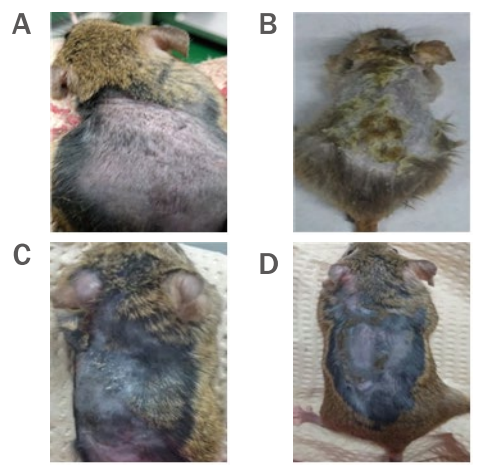

Figure 1. Sensory assessment in NC/Nga mice.

(A) Control, (B) AD-induced, (C) E oil-treated, and (D) ER oiltreated mice. To induce AD, $150 \mu \mathrm{L}$ of $0.2 \%$ DNCB was applied on the hair-removed dorsal skin of NC/Nga mice twice a day for 3 weeks beginning on the fourth day of the application of $200 \mu \mathrm{L}$ of $1 \%$ DNCB, which was prepared by adding $1 \mathrm{~g}$ of DNCB to $100 \mathrm{~mL}$ of acetone/olive oil (3:1). After AD induction, $150 \mu \mathrm{L}$ of $1 \%$ ethanol, prepared by mixing $100 \mathrm{~mL}$ of $\mathrm{E}$ oil and $1 \mathrm{~mL}$ of ethanol, was applied twice a day for 6 days for recovery in the E oil-treated group. In the ER oil-treated group, $150 \mu \mathrm{L}$ of ER oil, prepared by adding $2 \mathrm{~mL}$ of $\mathrm{E}$ oil to $100 \mathrm{~mL}$ of $\mathrm{R}$ oil and then adding $1 \mathrm{~mL}$ of ethanol to $2 \%$ ER oil, was applied twice a day for 6 days for recovery. E oil and ER oil both improved recovery for $A D$, with ER oil having a higher therapeutic efficacy. AD, atopic dermatitis; $E$ oil, evening primrose oil; R oil, rosemary oil; ER oil, evening primroserosemary mixed oil; DNCB, 1-chloro-2,4-dinitrobenzene.

와 이차항체[horseradish peroxidase (HRP)-conjugate goat anti-mouse IgE, 1:10,000]를 $1 \mathrm{~h}$ 동안 처리하고 발색 처리한 후 ELISA reader로 $450 \mathrm{~nm}$ 에서 흡광도를 측정하였다. $\mathrm{IgE}$ 정 량은 대조군에 대한 실험군의 백분율로 표시하였다.

\section{1. 비만세포 측정}

비만세포(mast cell)의 탈과립 변화에 대한 조사를 위하여 $10 \% \mathrm{NBF}$ 으로 고정된 조직을 파라핀으로 포매한 다음 초박 절 편기를 이용하여 $5 \mu \mathrm{m}$ 의 두께로 절편하였다. 절편 조직은 탈 파 라핀 과정과 알코올 함수과정을 거쳐 증류수로 세척한 후 절편

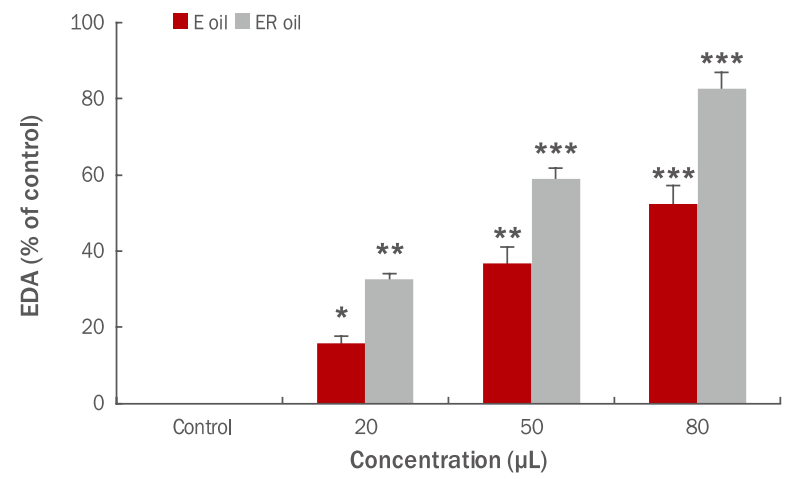

Figure 2. EDA of E oil and ER oil.

Initially, $2 \mathrm{~mL}$ of ethanol sample solutions containing 20,50 , and $80 \mu \mathrm{L}$ of $\mathrm{E}$ oil and ER oil was added to $1 \mathrm{~mL}$ of $0.2 \mathrm{mM} \mathrm{DPPH}$ and was left to stand for $30 \mathrm{~min}$. Then, the absorbance at $517 \mathrm{~nm}$ was measured, and the decreasing absorbance rates of the oiltreated groups and control group were expressed as percentages. The E oil- and ER oil-treated groups showed statistically significant increases compared with those of the control group, with $80 \mu \mathrm{L}$ treatment in particular leading to a higher statistically significant increase. In addition, ER oil treatment led to higher activation than that of $\mathrm{E}$ oil single treatment, indicating synergistic therapeutic effects of mixed oil. The data are shown as the $M \pm S D$ for triplicate experiments, with the significance of the difference from the control given as ${ }^{*} p<0.05,{ }^{* *} p<0.01$, and ${ }^{* * *} p<0.001$. EDA, electron donating activity; $E$ oil, evening primrose oil; ER oil, evening primrose-rosemary mixed oil; DPPH, 2,2-diphenyl-1picrylhydrazyl; $\mathrm{M} \pm \mathrm{SD}$, mean \pm standard deviation.

조직을 toluidine blue solution $(\mathrm{pH} 0.5)$ 로 $1 \mathrm{~h}$ 동안 염색한 다 음 증류수로 세척 후 탈수와 투명과정을 거쳐 봉입하여 광학현 미경(Olympus)으로 관찰하였다. 모든 영상은 영상카메라를 이 용 $\mathrm{TIF}$ 로 저장하였고 이는 현미경의 빛 강도와 영상분석프로 그램을 통하여 $450 \mathrm{MHz}$ 펜티엄 프로세스와 영상보드(Media Cybernetics)가 장착된 컴퓨터시스템을 이용하여 측정하였다.

\section{2. 통계 처리}

본 실험의 모든 자료는 Statistical Package for the Social Sciences (SPSS) 12.0 program (IBM, USA)에 의하여 처리하

Table 2. Weight changes of body and organs in NC/Nga mice

\begin{tabular}{lccc}
\hline & & & Weight (g) \\
\cline { 2 - 4 } Division & Control & AD & $\begin{array}{c}\text { E oil } \\
\text { (After } 6 \text { days) }\end{array}$ \\
Whole body & $25.5 \pm 1.43$ & $26.6 \pm 1.59$ & $0.181 \pm 0.03$ \\
Heart & $0.183 \pm 0.04$ & $26.8 \pm 3.26$ & $26.7 \pm 1.92$ \\
Intestine & $2.474 \pm 0.15$ & $0.185 \pm 0.05$ & $0.180 \pm 0.02$ \\
Spleen & $0.156 \pm 0.03$ & $2.458 \pm 0.26$ & $0.153 \pm 0.04$ \\
Liver & $1.685 \pm 0.18$ & $0.158 \pm 0.06$ & $1.693 \pm 0.17$ \\
Lung & $0.179 \pm 0.07$ & $1.729 \pm 0.15$ & $0.151 \pm 0.05$ \\
\hline
\end{tabular}

$\mathrm{AD}$, atopic dermatitis; E oil, evening primrose oil; ER oil, evening primrose-rosemary mixed oil; $p>0.05$. 


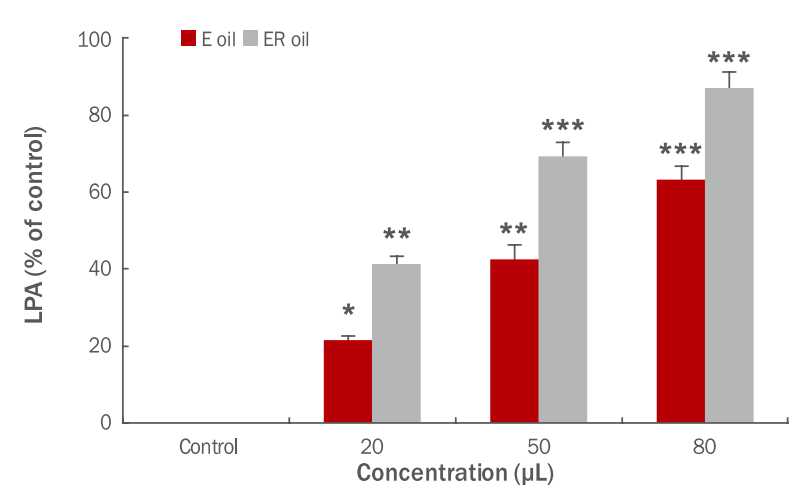

Figure 3. LPA of E oil and ER oil.

Ethanol sample solutions containing 20,50 , and $80 \mu \mathrm{L}$ of $\mathrm{E}$ oil and ER oil was added to a mixture of $2.52 \%$ linoleic acid resolved in ethanol and $0.05 \mathrm{M} \mathrm{PBS}$, and the samples were then incubated in a dark place at $40^{\circ} \mathrm{C}$ for $24 \mathrm{~h}$. After the incubation, $0.1 \mathrm{~mL}$ was added to $30 \%$ ammonium thiocyanate and $0.02 \mathrm{M}$ ferrous chloride and then left at room temperature for $1 \mathrm{~h}$. The absorbance was measured at $500 \mathrm{~nm}$ and expressed as a percentage. The measurement results of the oil-treated groups showed statistically significant increases compared with that of the control group. In addition, the ER oil treatment led to higher activation than that of $E$ oil single treatment, which indicated synergistic therapeutic effects of mixed oil. The data indicates the $M \pm S D$ for triplicate experiments, which was significantly different from that of the control $\left({ }^{*} p<0.05 ;{ }^{* *} p<0.01 ;{ }^{* * *} p<0.001\right)$. LPA, lipid peroxidation activity; E oil, evening primrose oil; ER oil, evening primrose-rosemary mixed oil; PBS, phosphate buffered saline; $\mathrm{M} \pm \mathrm{SD}$, mean \pm standard deviation.

였으며 모든 실험 자료 값은 mean \pm standard deviation $(\mathrm{M} \pm$ $\mathrm{SD}$ )로 나타냈다. Student's $t$-test에 의하여 통계적 유의성을 비교하였고 $p<0.05$ 을 유의한 수준으로 하였다.

\section{Results and Discussion}

\section{1. 체중 및 장기 무게측정}

$\mathrm{AD}$ 모델인 $\mathrm{NC} / \mathrm{Nga}$ 생쥐에 대한 체중 및 장기 무게 변화에 대한 측정 결과, 체중의 경우 대조군과 실험군 모두에서 유의한 차이가 나타나지 않았으며 $(p>0.05)$, 심장, 장, 비장, 간, 폐 등 장기 무게에 있어서도 대조군과 실험군간에 유의한 차이가 나타 나지 않았다( $p>0.05$; Table 2). 이는 Han \& Seo (2014)의 아토 피피부염을 유발한 $\mathrm{NC} / \mathrm{Nga}$ 생쥐에서 허브의 혼합오일이 체중 과 장기에 아무런 영향을 주지 않았다는 연구 결과와 일치하는 것이다.

\section{2. 관능평가}

관능평가 결과 총 15 점 중에서 $\mathrm{AD}$ 유발군은 $13 \pm 1.62, \mathrm{E}$ oil 처리군에서는 $4 \pm 0.71$ 로 나타나 $\mathrm{AD}$ 유발군에 비하여 유의한 차 이를 보였으며( $p<0.01), \mathrm{ER}$ oil 처리군은 $1 \pm 0.07$ 로 $\mathrm{AD}$ 유발군 에 비하여 유의한 차이를 나타냈다 $(p<0.001 ;$ Table 3$)$. 동물 실 험의 사진 결과에서도 일치함을 알 수 있었다(Figure 1).

이는 $\mathrm{AD}$ 에 대하여 $\mathrm{E}$ oil와 $\mathrm{ER}$ oil의 처리가 치료적 효능이 있 으며, ER oil이 더 높은 효과가 있음을 나타내는 것이며, Han \& Seo (2014)의 연구에서 브랜딩한 허브오일의 효과가 더 높다는 보고와도 일치하는 것이다.

\section{3. $\mathrm{EDA}$ 측정}

$\mathrm{E}$ oil과 ER oil이 $20,50,80 \mu \mathrm{L}$ 포함된 에탄올 시료의 $\mathrm{EDA}$ 를 확인하였다. $\mathrm{E}$ oil의 $\mathrm{EDA}$ 는 각각 $15.8 \%$ ( $p<0.05), 36.7 \%$ $(p<0.01), 52.4 \%$ ( $p<0.001)$ 로 대조군 대비 유의한 증가를 나 타냈으며, $\mathrm{ER}$ oil의 $\mathrm{EDA}$ 도 각각 $32.5 \%$ ( $p<0.01), 58.9 \%$ $(p<0.001), 82.6 \%$ ( $p<0.001)$ 로 대조군 대비 유의한 증가를 나타 냈다(Figure 2).

$\mathrm{EDA}$ 는 E oil의 경우 대조군 대비 유의한 증가를 보였으며, 특 히 $80 \mu \mathrm{L}$ 의 처리에서 매우 유의한 증가를 나타냈다 $(p<0.001)$. $\mathrm{ER}$ oil의 경우에도 역시 대조군 대비 유의한 증가를 나타냈으며 $(p<0.001), \mathrm{ER}$ oil은 $\mathrm{E}$ oil의 단독처리보다 더 높은 활성을 나타

Table 3. Sensory assessment in NC/Nga mice

\begin{tabular}{lcccc}
\hline & & \multicolumn{2}{c}{ Sensory assessment } & \\
\cline { 2 - 5 } Division & Total score & AD & E oil & ER oil \\
Erythema & 3 & 3 & 1 & 1 \\
(After 6 days) & 1 & 0 \\
Edema & 3 & 2 & 1 & 0 \\
Pruritus & 3 & 3 & 1 & 0 \\
Excoriation & 3 & 3 & 0 & 0 \\
Scaling/dryness & 3 & 2 & $4 \pm 0.71^{* *}$ & $1 \pm 0.07^{* * *}$ \\
Total & 15 & $13 \pm 1.62$ & 1 & 1 \\
\hline
\end{tabular}

$\mathrm{AD}$, atopic dermatitis; E oil, evening primrose oil; ER oil, evening primrose-rosemary mixed oil; ${ }^{* *} p<0.01 ;{ }^{* * *} p<0.001$. 

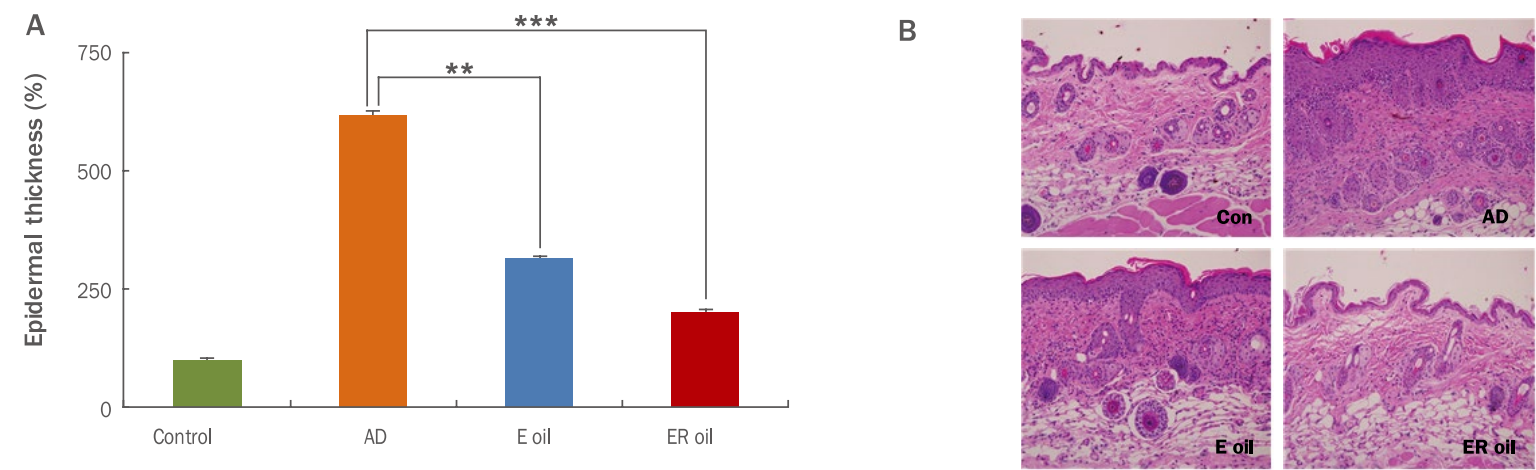

\section{Figure 4. Epidermal thickness of E oil and ER oil.}

(A) The epidermal thickness of AD-induced mice was measured after treating with E oil and ER oil for 6 days. To measure the epidermal thickness, biopsy tissues were fixed in $10 \%$ NBF, embedded in paraffin, and then sliced into 5- $\mu$ m-thick slices. The slices were treated with Harris hematoxylin solution and $1 \% \mathrm{HCl}$-alcohol, re-treated with ammonia water and lithium carbonate, and followed by a 3-min treatment with $1 \%$ eosin-alcohol dehydrate solution. The results of optical microscopy measurements showed a statistically significant reduction in the effects for the E oil- and ER oil-treated groups relative to those of the AD-induced group. Moreover, the ER oil treatment led to higher reduction effects than that for the $\mathrm{E}$ oil single treatment. The data is presented as the $\mathrm{M} \pm \mathrm{SD}$ for triplicate experiments, and the significance of the difference from the AD group is given as ${ }^{* *} p<0.01$ or ${ }^{* * *} p<0.001$. (B) The epidermal thickness was photographed under an optical microscope $(\times 200)$. The results of the optical microscopy observation of the epidermal thickness showed apparent hyperplasia in the AD-induced group and a statistically significant reduction for the $\mathrm{E}$ oil- and ER oil-treated groups. In particular, the ER oil-treated group showed a significant reduction, and the recovery was similar to that of the control group. Con, control; $A D$, atopic dermatitis; E oil, evening primrose oil; ER oil, evening primrose-rosemary mixed oil; NBF, neutral buffered formalin; $\mathrm{HCl}$, hydrogen chloride; $\mathrm{M} \pm \mathrm{SD}$, mean \pm standard deviation.

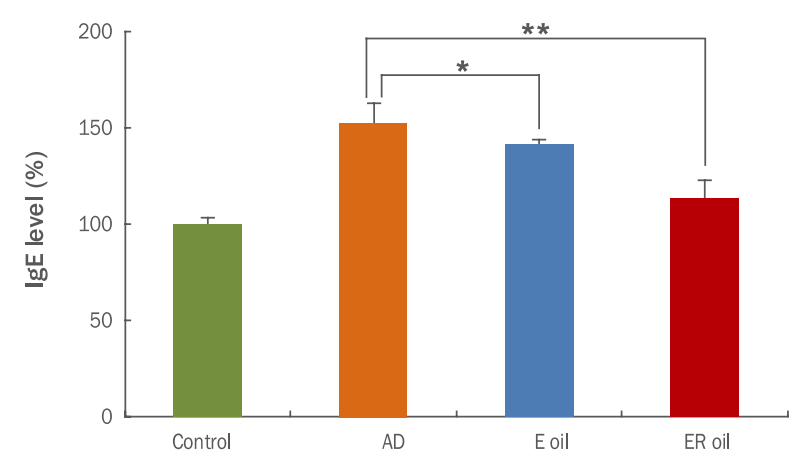

Figure 5. Changes in IgE level in serum.

Initially, $1.5 \mathrm{~mL}$ of blood was collected from the retro-orbital sinus of NC/Nga mice, followed by centrifugation at 3,000 rpm for $20 \mathrm{~min}$ at $4^{\circ} \mathrm{C}$. The supernatant liquid was treated with HRP and conjugate goat anti-mouse IgE (at a dilution of $1: 10,000$ ) by using a IgE ELISA kit for $1 \mathrm{~h}$, and then the absorbance at $450 \mathrm{~nm}$ was measured. The measurement results showed a considerable increase in absorbance for the $\mathrm{AD}$-induced group relative to that in the control group and a statistically significant decrease in absorbance in the E oil- and ER oil-treated groups relative to that in the ADinduced group. The data is given as the $M \pm S D$ for triplicate experiments, and the significance of differences from the $A D$ group are given as ${ }^{*} p<0.05 ;{ }^{* *} p<0.01$ ). IgE, immunoglobulin $E ; A D$, atopic dermatitis; $E$ oil, evening primrose oil; ER oil, evening primrose-rosemary mixed oil; HRP, horseradish peroxidase; ELISA, enzyme-linked immunosorbent assay; $\mathrm{M} \pm \mathrm{SD}$, mean \pm standard deviation.
냄으로써 치료적 상승효과가 있음을 증명하였다. 이는 Cha et al. (2010)의 연구에서 4종류 이상 허브오일을 브랜딩한 혼합오 일이 각각의 단독오일보다 효능이 더 높았다는 보고와 일치하는 것이다.

\section{LPA 측정}

$\mathrm{E}$ oil와 $\mathrm{ER}$ oil이 $20,50,80 \mu \mathrm{L}$ 포함된 에탄올 시료의 $\mathrm{LPA}$ 를 측정한 결과 $\mathrm{E}$ oil은 각각 $21.4 \%$ ( $p<0.05), 42.5 \%$ ( $p<0.01)$, $63.2 \%$ ( $p<0.001$ )로 대조군에 비하여 유의한 증가를 나타냈으며, $\mathrm{ER}$ oil에서도 각각 $41.2 \%$ ( $p<0.01), 69.4 \%$ ( $p<0.001), 87.0 \%$ $(p<0.001)$ 로 대조군 대비하여 유의한 증가를 나타냈다(Figure 3).

본 연구에서 $\mathrm{E}$ oil와 $\mathrm{ER}$ oil은 높은 LPA을 나타내고 있으며, 특히 ER oil의 처리가 E oil만의 처리보다 더 높은 LPA을 나 타냄으로써 $\mathrm{ER}$ oil의 상승효과를 증명하고 있다. 이는 Choi \& $\operatorname{Kim}$ (2009)이 허브의 브랜딩한 혼합오일의 치료가 단독오일의 치료보다 체구성물인 지방변화와 체형에 대한 효능이 더 높았다 는 보고와 일치하는 것이다. 또한, 아토피피부염 병변과 산화적 손상이 밀접한 관련이 있다는 Huh et al. (2004)의 연구결과를 고려해 볼 때, 본 연구의 관능평가에서도 E oil와 ER oil이 높은 항산화능을 나타내고 있어 $\mathrm{AD}$ 의 치료적 효능이 있음을 알 수 있 다. 


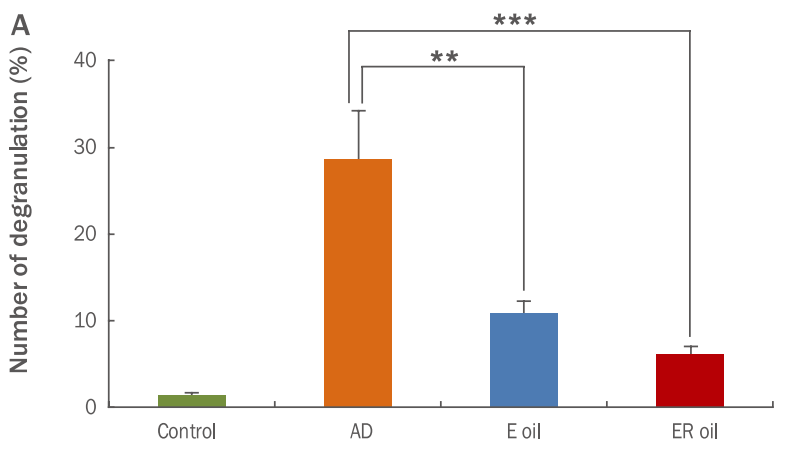

B

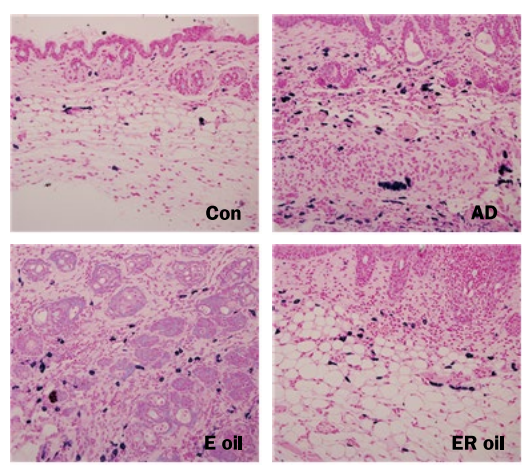

Figure 6. Numerical changes in degranulated mast cells.

(A) To examine mast cell degranulation changes, biopsy tissues were fixed in 10\% NBF, embedded in paraffin, and sliced into 5- $\mu$ m-thick slices, followed by deparaffinization and alcohol hydration. The slices were washed in distilled water and stained with toluidine blue solution ( $\mathrm{pH}$ 0.5) for $1 \mathrm{~h}$, followed by observation under an optical microscope. The AD-induced group had a considerably higher number of degranulated mast cells than that of the control group. In addition, the E oil and ER oil groups showed a statistically significant decrease relative to that of the AD-induced mice were treated with $E$ oil and ER oil for 6 days. The data is given as the $M \pm S D$ for triplicate experiments, and the significance of differences from the AD group are given as ${ }^{* *} p<0.01$ or $\left.{ }^{* * *} p<0.001\right)$. (B) The degranulated mast cells were photographed under an optical microscope $(\times 200)$. The results of the microscopic observation of mast cells showed a minority of mast cells in the control group and larger numbers of mast cells and degranulated cells in the AD-induced group. There was a large reduction in the numbers of mast cells and degranulation cells in the E oil-treated group as well as an apparent reduction in the numbers in the ER oil-treated group relative to those in the AD-induced group. Con, control; AD, atopic dermatitis; E oil, evening primrose oil; ER oil, evening primrose-rosemary mixed oil; NBF, neutral buffered formalin; $\mathrm{M} \pm S D$, mean \pm standard deviation.

\section{5. 표피두께 측정}

\section{1) 표피두께}

표피두께는 대조군 $100.0 \%(17.86 \pm 1.32)$ 에 대비하여 $\mathrm{AD}$ 유

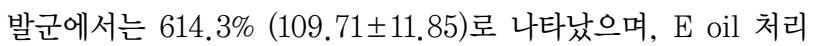
시 $314.5 \%(56.17 \pm 8.23 ; p<0.01)$, ER oil의 처리시는 $200.8 \%$ $(35.87 \pm 2.94 ; p<0.001)$ 로 각각 나타나 대조군에 비하여 유의한 감소를 보였다(Figure $4 \mathrm{~A})$.

\section{2) 표피두께의 광학현미경적 관찰}

표피에 대한 광학현미경 관찰 결과 대조군에서는 각질층과 표 피층이 잘 관찰되었고 진피층에서는 지선과 털이 관찰된 반면, $\mathrm{AD}$ 유발군에서는 현저한 표피두께의 비후가 관찰되었다. 한편 $\mathrm{E}$ oil 처리군에서는 $\mathrm{AD}$ 유발군에 비하여 표피두께가 유의하게 감소 되었으며, $\mathrm{ER}$ oil 처리군에서도 표피의 두께가 $\mathrm{AD}$ 유발군 에 비하여 현저하게 감소되어 대조군과 비슷한 회복 양상을 보였 으며 지선 및 털세포도 관찰되었다(Figure 4B).

표피 두께증가는 $\mathrm{AD}$ 이나 산화적 손상과 같은 병변, $\mathrm{IFN} \gamma$ 및 $\mathrm{TNF} \alpha$ 와 같은 사이토카인, 혹은 피부의 진피층의 비후나 염증에 의한 현상이나(Fridovich, 1975), 표피의 각질층이 급성 또는 만 성으로 손상될 경우 표피에 존재하는 $N$-methyl-D-aspartate (NMDA) 수용체의 과 활성에 의한 ROS의 생성 및 피부손상에 따른 항상성 회복을 위한 대사과정이 진행되어 활발한 표피증 식이 일어남으로써 피부장벽의 비후를 초래한다고 알려져 있다 (Kim et al., 2013).
본 연구 결과에서 표피두께는 $\mathrm{AD}$ 유발군에서는 대조군에 비 하여 매우 높은 표피두께 증가가 나타났으며, E oil와 ER oil을 각각 처리한 경우에서는 표피두께가 $\mathrm{AD}$ 유발군에 비하여 유의하 게 감소한 것으로 나타났다. 광학현미경적 관찰에 있어서도 $\mathrm{AD}$ 유발군은 표피의 두께가 대조군에 비하여 현저히 비후된 반면, $\mathrm{E}$ oil와 ER oil 처리에서는 모두 $\mathrm{AD}$ 유발군에 비하여 유의한 두께 의 감소를 보임으로써 정량적인 분석 결과와도 일치하였다. 또한 본 ER oil의 처리가 E oil만의 처리에 비하여 더 높은 표피두께 감소능을 보였다. 이는 앞에서 행한 항산화능의 분석에서와 같이 $\mathrm{ER}$ oil 처리가 E oil만의 단독처리 보다 높은 효능을 나타냄으로 써 ER oil의 상승효과를 증명하는 것이며, Han \& Seo (2014)의 3 개의 허브오일을 브랜딩한 혼합오일이 각각의 단독오일보다 현 저한 표피두께의 감소를 나타냈다는 보고와 일치하는 것이다. 또 한 본 연구에서 $\mathrm{ER}$ oil을 비롯한 $\mathrm{E}$ oil이 피부두께를 감소시킨 것은 일부 $\mathrm{TNF} \alpha$ 의 발현 억제도 있겠지만 그 보다는 $\mathrm{AD}$ 유발에 따른 표피손상으로 인해 유도되는 산화적 손상을 억제시킴으로 써 피부장벽의 손상을 저해한 결과일 가능성이 클 것으로 사료된 다.

\section{6. $\lg \mathrm{E}$ 측정}

$\mathrm{IgE}$ 의 양적 측정에서 $\mathrm{AD}$ 유발군은 대조군인 $100.0 \%(0.053$ $\pm 0.007)$ 대비 $152.8 \%(0.081 \pm 0.009)$ 로 많은 증가를 하였으 며, $\mathrm{E}$ oil 처리에서는 $141.5 \%(0.075 \pm 0.004 ; p<0.05)$, ER oil 처리에서는 $113.2 \%(0.060 \pm 0.003 ; p<0.01)$ 로 나타나 모두 $\mathrm{AD}$ 
유발군에 비하여 유의한 감소를 나타냈다(Figure 5).

$\mathrm{AD}$ 병변의 주된 임상적 특징의 하나인 소양감 원인으로는 혈 청 내 높은 $\mathrm{IgE}$ 의 수준과 비만세포의 탈과립에 기인한 것으로 알려져 있으며(Sudo et al., 2001; Yamashita et al., 2005), $\mathrm{TNF} \alpha$ 와 ROS는 nuclear factor kappa B $(\mathrm{NF} \kappa \mathrm{B})$ 를 자극하고 이는 IL4의 생성을 유도하며 이같이 유도된 IL4는 IgE의 생성에 관여한다고 하였다(Lee et al., 2008; Lim et al., 1995).

본 연구에서 $\operatorname{IgE} \mathrm{E}$ 의 양적변화는 $\mathrm{AD}$ 유발군에서는 대조군에 비 하여 높게 나타난 반면, $\mathrm{E}$ oil 처리와 $\mathrm{ER}$ oil 처리 시 $\mathrm{AD}$ 유발군 에 비하여 각각 유의한 감소를 보였다. 또한, 오일 처리군이 $\mathrm{AD}$ 유발군에서 높게 나타난 $\mathrm{IgE}$ 를 유의하게 감소시켰으며, $\mathrm{ER}$ oil 의 처리가 E oil만의 처리에 비하여 높게 나타남으로써 혼합오 일이 단독오일보다 높은 상승효과가 있음을 알 수 있었다. 이는 Liu et al. (2011)의 아토피피부염 이완 시 IgE 수준이 높게 나타 났다는 연구 결과와 Seo (2014)의 연구에서 아토피피부염 모델 에서 3 종류 허브의 혼합오일이 단독오일보다 유의한 $\operatorname{IgE}$ 의 감소 를 나타냈다는 보고와도 일치하는 것이다. 또한 본 연구에서 사 용한 $\mathrm{E}$ oil와 $\mathrm{ER}$ oil에 의한 $\mathrm{IgE}$ 의 감소는 이들이 $\mathrm{EDA}$ 및 $\mathrm{LPA}$ 과 같은 항산화 효과에 의하여 $\mathrm{ROS}$ 의 생성저해는 물론 일부 $\mathrm{TNF} \alpha$ 의 발현 억제에도 영향을 준 결과일 것으로 생각된다.

\section{7. 비만세포 측정}

1) 탈과립 수

비만세포의 탈과립 수는 대조군에서 $1.4 \%( \pm 0.3)$ 로 나타났으 며, $\mathrm{AD}$ 유발군에서는 $28.6 \%$ ( \pm 5.6$)$ 로 매우 높게 나타났다. 이 에 비하여 $\mathrm{E}$ oil 처리군에서는 $10.9 \%( \pm 1.4 ; \mathrm{p}<0.01)$, ER oil 처리군에서는 $6.2 \%( \pm 0.9 ; p<0.001)$ 로 각각 나타나 $\mathrm{AD}$ 유발군 대비 유의한 감소를 보였다(Figure $6 \mathrm{~A}$ ).

\section{2) 비만세포의 현미경적 관찰}

비만세포의 현미경 관찰 결과 대조군에서는 소수의 비만세포 가 관찰된 반면, $\mathrm{AD}$ 유발군에서는 많은 수의 비만세포가 관찰되 었으며 탈과립된 세포도 많이 관찰되었다. 이에 비하여 E oil 처 리군에서는 $\mathrm{AD}$ 유발군에 비하여 비만세포의 수와 탈과립이 많이 감소되었으며, $\mathrm{ER}$ oil 처리군에서도 $\mathrm{AD}$ 유발군에 비하여 현저한 비만세포의 수와 탈과립의 감소를 나타냈다(Figure 6B).

본 실험에서 비만세포와 탈과립의 변화는 대조군에서는 탈과 립이 $1.4 \%$ 로 나타난 데 비하여 $\mathrm{AD}$ 유발군에서는 매우 높게 나타 났으며, $\mathrm{E}$ oil와 $\mathrm{ER}$ oil의 처리에서는 $\mathrm{AD}$ 유발군에 비하여 모두 유의한 감소를 보였다. 비만세포에 대한 광학현미경적 관찰에서 도 $\mathrm{AD}$ 유발군에서는 다수의 비만세포와 탈과립이 관찰된 대신 오일 처리군에서는 $\mathrm{AD}$ 유발군에 비하여 유의한 수적 감소를 보 임으로써 정량적 결과와 일치하였다. 본 실험 결과에서, $\mathrm{E}$ oil와 $\mathrm{ER}$ oil의 처리가 $\mathrm{AD}$ 유발군에 비하여 탈과립 수의 감소를 나타
냈으며, ER oil과 같은 혼합오일이 E oil만의 단독 오일에 비하 여 더 높은 감소현상을 보임으로써 혼합오일의 상승효과를 증명 하였다.

이는 Cha et al. (2010)의 3종류의 허브오일을 브랜딩한 혼 합오일이 각 단독오일보다 비만세포와 탈과립 수를 유의하게 감 소시켰다는 연구결과와 일치하는 것이며, 이 같은 현상은 $\mathrm{TNF} \alpha$ 와 ROS에 의해 활성화된 $\mathrm{NF \kappa B}$ 는 세포고사인자인 caspase 3 의 발현이나, 비만세포의 탈과립을 유도한다는 것을 고려해 볼 때 (Petrache et al., 2000), 오일들의 항산화 작용이 NFKB의 활 성을 방해함으로써 비만세포에 영향을 준 것으로 생각된다.

$\mathrm{AD}$ 는 소양감을 동반한 만성염증성 피부 질환으로 기관지천식 이나 결막염 등과 같은 질환과 동반하는 경향이 많다(Beltrani, 2003). $\mathrm{AD}$ 의 치료로는 현재 스킨케어 및 약물요법이 있는데 약 물요법으로는 스테로이드계통의 외용제나 연고, 외용보습제 및 항히스타민제와 같은 처방이 사용되고 있다(Lee et al., 2008). 최근 $\mathrm{ROS}$ 가 $\mathrm{AD}$ 의 유발요인의 하나로 알려지면서 $\mathrm{AD}$ 와 $\mathrm{ROS}$ 간의 상호작용을 밝히려는 연구가 시도되고 있으며(Seo, 2014), 특히 허브에서 생산되는 오일이나 추출물이 항산화, 항염, 항균 등에 유효한 효능이 있다고 밝혀지면서 이를 이용한 피부 병변의 대체적인 치료제의 개발이 시도되고 있다(Owlia et al., 2007). 본 연구에서 $\mathrm{NC} / \mathrm{Nga}$ 생쥐의 $\mathrm{AD}$ 유발모델에 대한 $\mathrm{E}$ oil와 여기 에 $\mathrm{R}$ oil을 혼합한 $\mathrm{ER}$ oil의 영향에 관한 연구 결과는 $\mathrm{AD}$ 의 치료 에 있어 허브오일을 이용한 아로마테라피적 측면에서 병변에 효 능이 높은 치료적 접근을 위한 자료적 활용 가치가 클 것으로 판 단되었다.

\section{Conclusion}

본 연구에서는 $\mathrm{AD}$ 유발모델인 $\mathrm{NC} / \mathrm{Nga}$ 생쥐를 대상으로 허브 오일인 $\mathrm{E}$ oil 및 $\mathrm{ER}$ oil에 대하여, 체중, 장기 무게 및 관능평가 를 비롯한 $\mathrm{EDA}$ 와 $\mathrm{LPA}$ 과 같은 항산화능 및 $\mathrm{AD}$ 가 유발된 생쥐의 조직으로부터 표피두께, $\operatorname{IgE}$ 양적 변화 및 비만세포의 탈과립에 대하여 상호 비교 조사하여 허브오일을 이용한 $\mathrm{AD}$ 치료에 활용 자료를 제공할 목적으로 연구를 하였다. 주요 결과는 다음과 같 다.

$\mathrm{AD}$ 유발모델인 $\mathrm{NC} / \mathrm{Nga}$ 생쥐에서 $\mathrm{AD}$ 유발 직후와 오일 처치 가 끝난 직후에 있어 체중과 장기 무게에는 대조군에 비하여 유 의한 차이가 나타나지 않았으며, 관능평가에 있어 $\mathrm{E}$ oil 또는 $\mathrm{ER}$ oil 처리군과 $\mathrm{AD}$ 유발군 간에 유의한 차이를 보였다. 또한 본 실 험에 사용된 $\mathrm{E}$ oil 및 혼합오일인 ER oil은 EDA 및 LPA에서의 항산화능을 보여주었으며, 특히 ER oil이 E oil만의 단독처리 보다 더욱 유의한 항산화 효과를 보여 주었다. 또한 $\mathrm{AD}$ 유발모 
델인 $\mathrm{NC} / \mathrm{Nga}$ 생쥐의 조직으로부터 측정한 표피두께를 비롯한 $\mathrm{IgE}$ 및 비만세포의 탈과립 조사에 있어서, $\mathrm{E}$ oil와 $\mathrm{ER}$ oil은 $\mathrm{AD}$ 유발군에 비하여 모두 유의한 감소 양상을 보였으며, 특히 혼합 오일인 $\mathrm{ER}$ oil은 단독오일인 $\mathrm{E}$ oil에 비하여 더욱 유의한 감소를 보였다.

본 연구에서처럼 $\mathrm{AD}$ 유도 병변에 서로 다른 두 종류 이상의 허브오일에 대한 단독 또는 혼합오일의 생리활성을 항산화 및 병 인적 측면에서 조사함은 향후 이를 바탕으로 아로마테라피적 접 근을 위한 과학적인 가능성을 제시하는데 기여할 수 있을 것으로 판단된다.

This work is part of the Seon Ju Kim's Ph.D thesis at the Chosun University, Gwangju, Korea.

\section{References}

Battaglia S. The complete guide to aromatherapy (2nd edition). Perfect Potion, Zillmere, p342, 2004.

Beltrani VS. The role of house dust mites and other aeroallergens in atopic dermatitis. Clinics in Dermatology, 21: 177-182, 2003.

Blois MS. Antioxidant determinations by the use of a stable free radical. Nature, 181: 1199-1200, 1958.

Bratton DL, Hamid Q, Boguniewicz M, Doherty DE, Kailey JM, Leung DY. Granulocyte macrophage colonystimulating factor contributes to enhanced monocyte survival in chronic atopic dermatitis. The Journal of Clinical Investigation, 95: 211-218, 1995.

Cha JH, Kim MJ, Kim HS, Kim YI. Effects of aromatherapy in blending oil of basil, lavender, rosemary, and rose on headache, anxiety and serum cortisol level in the middle-aged women. Journal of Korean Biological Nursing Science, 12: 133-139, 2010.

Choi MO, Kim JY. The effects of abdominal meridian massage on the body composition and body change according to essential blending or not. Jounal of the Korean Society of Cosmetology, 15: 1220-1228, 2009.

Festing MF, Baumans V, Combes RD, Halder M, Hendriksen CF, Howard BR, Lovell DP, Moore GJ, Overend P, Wilson MS. Reducing the use of laboratory animals in biomedical research: problems and possible solutions. Alternatives to Laboratory Animals, 26: 283-301, 1998. Fridovich I. Superoxide dismutases. Annual Review of
Biochemistry, 44: 147-159, 1975.

Han SH, Heo MH, Park JH, Lee YJ, Park MK. Aromatherapy. Hyunmoonsa, Seoul, p123, 2002.

Han SH, Seo YM. The effect of essential oil on atopic dermatitis model of NC/Nga mice. Journal of Korean Biological Nursing Science, 16: 219-225, 2014.

Hanifin JM. Atopic dermatitis. Journal of the American Academy of Dermatology, 6: 1-13, 1982.

Heo JH, Song HN, Jang SI. Effects of Gagambojungikgitang on the immune mediators regulation and wound healing in the rSj26 or chemical antigen induced atopic dermatitis model mice. The Korea Journal of Herbology, 23: 53-61, 2008.

Horiuchi Y, Bae S, Katayama I, Nishioka K. Therapeutic effects of streptococcal preparation OK-432 on atopic dermatitis-like lesions in NC/Nga mice: possible shift from a Th2- to Th1-predominance. Journal of Dermatological Science, 35: 187-197, 2004.

Horrobin DF. Essential fatty acid metabolism and its modification in atopic eczema. The American Journal of Clinical Nutrition, 71: 367S-372S, 2000.

Hou BB, Li Y. The study of antioxidant activity of grapefruit essential oil on edible oils. Food Research and Development, 32: 187-192, 2011.

Huh EJ, Ryu KH, Hur JK, Yoon JS, Kim YH, Kim JT, Hahn $\mathrm{H}$, Lee $\mathrm{KH}$, Lee JS. Increased reactive oxygen species production by peripheral blood mononuclear leukocytes, not by polymorphonuclear leukocytes, in atopic dermatitis. Allergy Asthma \& Respiratory Diseases, 14: 53-61, 2004.

Jung HA, Jung MJ, Kim JY, Chung HY, Choi JS. Inhibitory activity of flavonoids from Prunus davidiana and other flavonoids on total ROS and hydroxyl radical generation. Archives of Pharmacal Research, 26: 809-815, 2003.

Kalliomäki M, Kirjavainen P, Eerola E, Kero P, Salminen S, Isolauri E. Distinct patterns of neonatal gut microflora in infants in whom atopy was and was not developing. Journal of Allergy and Clinical Immunology, 107: 129134, 2001.

Kikuzaki H, Nakatani N. Antioxidant effects of some ginger constituents. Journal of Food Science, 58: 1407-1410, 1993.

Kim HJ, Shin JU, Lee KH. Atopic dermatitis and skin barrier dysfunction. Allergy Asthma \& Respiratory Disease, 1: 
20-28, 2013.

Lee SH, Min KJ, Lee KO, Sin JS, Kim YC. Effect of German chamomile oil application to atopic dermatitis mice on the change of serum IgE level. Jounal of the Korean Society of Cosmetology, 14: 337-345, 2008.

Lim BO, Yamada K, Yoshimura K, Watanabe T, Hung P, Taniguchi S, Sugano M. Free bile acids inhibit IgE production by mouse spleen lymphocytes stimulated by lipopolysaccharide and interleukins. Bioscience, Biotechnology, and Biochemistry, 59: 624-627, 1995.

Liu FT, Goodarzi H, Chen HY. IgE, mast cells, and eosinophils in atopic dermatitis. Clinical Reviews in Allergy \& Immunology, 41: 298-310, 2011.

Matsuda H, Watanabe N, Geba GP, Sperl J, Tsudzuki M, Hiroi J, Matsumoto M, Ushio H, Saito S, Askenase PW, et al. Development of atopic dermatitis-like skin lesion with IgE hyperproduction in NC/Nga mice. International Immunology, 9: 461-466, 1997.

Metzger $\mathrm{H}$. The high affinity receptor for IgE, FcepsilonRI. Novartis Foundation Symposium, 257: 51-59, 2004.

Oh HM, Kang YJ, Kim SH, Lee YS, Park MK, Heo JM, Sun JJ, Kim HJ, Kang ES, Kim HJ, et al. Agastache rugosa leaf extract inhibits the iNOS expression in ROS 17/2.8 cells activated with TNF- $\alpha$ and IL-1 $\beta$. Archives of Pharmacal Research, 28: 305-310, 2005.

Oh YL, Seo YM, Yang HO. Effect of rosemary extract on antioxidative activity and melanogenesis in cultured SKMEL-3 cells. Asian Journal of Beauty and Cosmetology, 9: 247-256, 2011.

Owlia P, Rasooli I, Saderi H. Antistreptococcal and antioxidant activity of essential oil from Matricaria chamomilla L. Research Journal of Biological Sciences, 2: 155-160, 2007.

Peng CH, Su JD, Chyau CC, Sung TY, Ho SS, Peng CC, Peng
RY. Supercritical fluid extracts of rosemary leaves exhibit potent anti-inflammation and anti-tumor effects. Bioscience, Biotechnology, and Biochemistry, 71: 22232232, 2007.

Petrache I, Otterbein LE, Alam J, Wiegand GW, Choi AM. Heme oxygenase-1 inhibits TNF-alpha-induced apoptosis in cultured fibroblasts. American Journal of Physiology - Lung Cellular and Molecular Physiology, 278: L312-L319, 2000.

Seo YM, Jeong SH. Effects of blending oil of lavender and thyme on oxidative stress, immunity, and skin condition in atopic dermatitis induced mice. Journal of Korean Academy of Nursing, 45: 367-377, 2015.

Seo YM. Recovery effect of blending oil on skin barrier damaged by atopic dermatitis. Journal of East-West Nursing Research, 20: 57-62, 2014.

Sudo N, Yu XN, Kubo C. Dehydroepiandrosterone attenuates the spontaneous elevation of serum IgE level in NC/ Nga mice. Immunology Letters, 79: 177-179, 2001.

Yamashita H, Michibata Y, Mizukami H, Ogihara Y, Morita A, Nose M. Dermal mast cells play a central role in the incidence of scratching behavior in mice induced by multiple application of the hapten, 2,4,6-trinitrochorobenzene. Experimental Dermatology, 14: 438-444, 2005.

Yamashita H, Tasaki D, Makino T, Matsuoka K, Nose M, Inagaki N, Mizukami $\mathrm{H}$. The role of IgE and repeated challenge in the induction of persistent increases in scratching behavior in a mouse model of allergic dermatitis. European Journal of Pharmacology, 605: 153-157, 2009.

Yoon SP, Kim BS, Ree JH, Lee SC, Kim YK. The environment and lifestyles of atopic dermatitis patients. Korean Journal of Dermatology, 37: 983-991, 1999. 
국문초록

\section{달맞이꽃종자유와 달맞이꽃종자유-로즈마리 혼합오일이 아토피피부염 동물 모델에 미치는 효과}

김선주, 박신희

조선대학교 보완대체의학과, 광주, 한국

목적: 본 연구는 달맞이꽃종자유와 달맞이꽃종자유에 로즈마리오일을 첨가한 혼합오일의 아토피피부염에 대한 치료적 대 체물질로의 활용가능성을 탐색하기 위해 시행하였다. 방법: $\mathrm{NC} / \mathrm{Nga}$ 생쥐를 대조군과 아토피피부염 유발군, 달맞이꽃종자 유 처치군 및 달맞이꽃종자유-로즈마리 혼합오일 처치군으로 나누어 항산화능과 지질과산화능을 분석하였다. 생검조직의 현미경 관찰과 $\mathrm{IgE}$ 분석, 비만세포(mast cell)의 탈과립 변화에 대한 조사를 하였다. 결과: 허브오일인 달맞이꽃종자유와 달맞이꽃종자유-로즈마리 혼합오일 처리시 전자공여능과 지질과산화능이 대조군 대비 모두에서 증가하였으며, 표피두께 는 모두 감소하였다. 광학현미경 관찰은 아토피피부염 유발군에서는 현저한 표피두께의 비후가 관찰되었으며 허브오일의 처리군에서는 아토피피부염 유발군에 비하여 두께가 감소하여 대조군과 비슷한 회복 양상을 보였다. IgE의 양적 측정 결과 아토피피부염 유발군은 증가를 나타내었으나, 허브오일 처리시는 감소를 나타냈다. 비만세포의 탈과립수는 허브오일 처리 시 아토피피부염 유발군 대비 감소하였다. 결론: 본 연구 결과는 피부염치료에 허브오일을 이용한 치료법으로 활용 가능성 을 확인하였으며, 두 종류 이상의 허브오일을 혼합사용 시 상승 효과가 있었다.

핵심어: 달맞이꽃종자유, 로즈마리오일, 아토피피부염, 항산화효과, 아로마테라피

\section{참고문헌}

김현정, 신정우, 이광훈. 아토피피부염과 피부 장벽 이상. 알레르기 천식 호흡기질환, $1: 20-28,2013$. 서영미. 아토피피부염의 손상된 피부장벽에 대한 혼합오일의 회복 효과. 동서간호학연구지, 20: 57-62, 2014.

오용열, 서영미, 양현옥. 배양 SK-MEL-3세포에 있어서 로즈마리 추출물의 항산화능 및 멜라닌화에 대한 영향. 아시안뷰 티화장품학술지, 9: 247-256, 2011.

윤성필, 김병수, 이주흥, 이승철, 김영근. 아토피 피부염 환자의 생활 환경 및 생활 습관에 대한 연구. 대한피부과학회지,

37: 983-991, 1999.

이순희, 민경진, 이경옥, 신정섭, 김영철. 아토피성 피부염에 German Chamomile 오일도포가 혈청 $\mathrm{IgE}$ 양 변동에 미치는 영향. 한국미용학회지, 14: $337-345,2008$.

최미옥, 김주연. 에센셜 블렌딩 유, 무에 따른 복부경락마사지의 체성분 및 신체 변화 효과. 한국미용학회지, 15: 1220 1228, 2009.

한선희, 허명행, 박진희, 이은진, 박미경. 여성건강과 아로마테라피. 현문사, 서울, $\mathrm{p} 123,2002$.

허은주, 유경환, 허재균, 윤종서, 김영훈, 김진택, 한훈, 이권행, 이준성. 아토피피부염에서 말초혈액 단핵구의 활성산소 생성 증가. 알레르기 천식 호흡기질환, 14: 53-61, 2004.

허정훈, 송한나, 장선일. $\mathrm{rSj} 26$ 또는 화학 항원 유도 아토피 피부염 마우스 모델에서 가감보중익기탕의 면역 매개물 조절

및 상처치료 효과. 대한본초학회지, 23: 53-61, 2008. 


\title{
中文摘要
}

\section{月见草油和月见草油-迷迭香混合油对特应性皮炎动物模型的影响}

\author{
金善珠, 朴信姬 \\ 朝鲜大学补完代替医学科, 光州, 韩国
}

目的: 本研究旨在探讨月见草油（evening primrose oil，E油）和月见草油-迷迭香混合油（evening primroserosemary mixed oil，ER油）作为治疗特应性皮炎的替代物质的可能性。方法: NC/Nga小鼠分为对照组、特应性 皮炎诱导组、E油组和ER油处理组。然后分析了抗氧化作用和脂质过氧化活性的影响。此外, 在显微镜下, 观察组 织活检标本，测定免疫球蛋白 $\mathrm{E}$ (immunoglobulin $\mathrm{E}, \lg \mathrm{E}$ ) 水平，评估肥大细胞脱颗粒的影响。结果：与对照组相 比, E油和ER油处理组均有增加供电子活性和脂质过氧化活性, 以及其表皮厚度均减少。在显微镜观察下, 特应性 皮炎诱导组的表皮厚度显著增加, 而 $E$ 油处理组和ER油处理组与特应性皮炎诱导组相比厚度减少, 并恢复到与对照 组相似的程度。定量测量显示特应性皮炎诱导组的IgE水平增加, 而E油组和ER油组的IgE水平下降。E油组和ER油 组与特应性皮炎诱导组相比, 肥大细胞脱颗粒减少。结论: 研究结果表明, 草药油如E油和ER油可能被用于治疗皮 炎, 而使用两种或多种植物油的混合油可能提高疗效。

关键词: 月见草油, 迷迭香油, 特应性皮炎, 抗氧化效能, 芳香疗法 